\title{
Pseudoalteromonas spp. phages, a significant group of marine bacteriophages in the North Sea
}

\author{
Antje Wichels*, Gunnar Gerdts, Christian Schütt
}

Alfred-Wegener-Institut für Polar- und Meeresforschung, Biologische Anstalt Helgoland, 27498 Helgoland, Germany

\begin{abstract}
The occurrence and distribution of specific bacteriophages of marine Pseudoalteromonas spp. in the North Sea (North Sea phages) and their genetic relationship to several previously isolated marine phage species from waters of the Helgoland Roads (German Bight, Helgoland phages) were investigated. During 3 cruises from the Elbe estuary to western Norwegian waters, phages were concentrated by ultrafiltration. Detection and isolation of North Sea phages were performed by plaque assay, with 70 host bacteria of the genus Pseudoalteromonas. The genetic relationship between North Sea phages from different stations and Helgoland phages, formerly described as Pseudoalteromonas spp. phages, was assessed by DNA-DNA hybridization. DNA probes were prepared using whole phage DNA derived from 13 Helgoland phages. This approach provides the first information on the distribution of specific Pseudoalteromonas spp. phage-host systems (PHS) in the North Sea. The occurrence of Pseudoalteromonas spp. phages, which are specific for the tested Pseudoalteromonas spp. host bacteria, was restricted to a narrow geographical region of the German Bight between $53^{\circ} 30^{\prime}$ and $57^{\circ} 00^{\prime} \mathrm{N}$ latitude. Most of the previously isolated Helgoland phages were highly host specific (54\%), whereas this was true for only some of the 39 North Sea phages $(16 \%)$. The most common Pseudoalteromonas spp. phage species found in the North Sea belong to the virus family Siphoviridae (species H103/1). Several phage strains within this phage species displayed different host sensitivity patterns.
\end{abstract}

KEY WORDS: Marine phages $\cdot$ Pseudoalteromonas $\cdot$ Phage DNA probes $\cdot$ North Sea

\section{INTRODUCTION}

The last decade has provided substantial information on the occurrence and abundance of virus-like particles (VLPs), as investigated by electron microscopy and epifluorescence direct counts. It is well established that VLPs are ubiquitously distributed and highly abundant, with concentrations of $10^{7}$ to $10^{10} \mathrm{VLPs}^{-1}$ in the aquatic environment (Bergh et al. 1989, Fuhrmann \& Suttle 1993, Bratbak et al. 1994, Wommack \& Colwell 2000). Despite this basic information there are still many open questions concerning their ecological role and functions in the bacterial communities. There is nearly no information on the distribution and abun-

*E-mail: awichels@awi-bremerhaven.de dance of specific natural marine phage-host systems (PHS) and their genetic relationship to other phages in the marine environment. Kellogg et al. (1995) have investigated the genetic diversity and distribution of vibriophages of the host bacterium Vibrio parahaemolyticus. The authors presented evidence for a widespread occurrence of genetically related phages in various marine habitats over a geographical distance of some 4500 miles $(\sim 7241 \mathrm{~km})$. These Vibrio sp. phages were members of the virus family Myoviridae, which were highly host specific. In contrast, by comparing host sensitivity patterns of marine phages isolated at different locations (i.e. west and east off the Azores), Moebus \& Nattkemper (1981) found PHS that were geographically restricted to different regions.

In the present report we describe the occurrence and geographical distribution of specific marine phage 

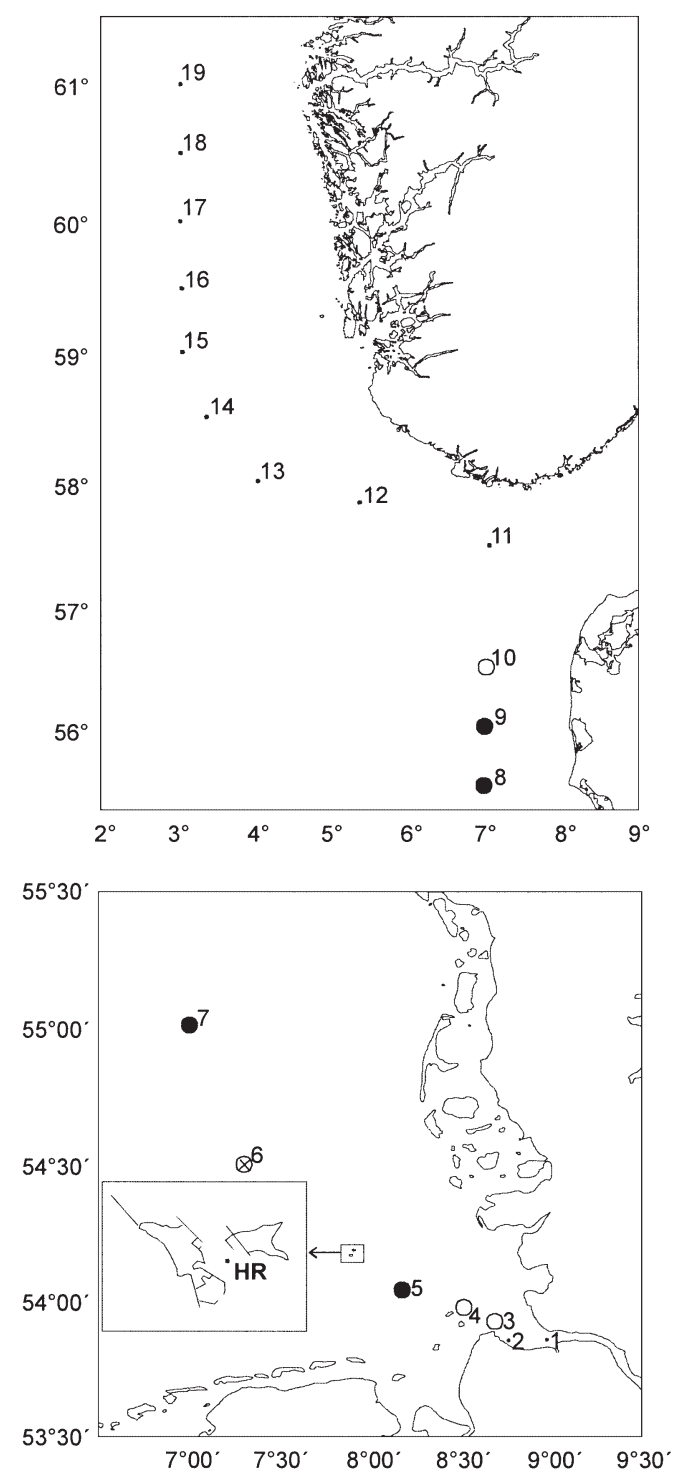

Fig. 1. Sampling area of the RV 'Heincke' Cruises HE49 (September 1993), 54 and 65 (April and October 1994) in the North Sea (German Bight to Norwegian waters). Stn Helgoland Roads (HR) is the origin of 70 phage-host systems used in this study (Moebus 1992a,b). Circles represent the occurrence of Pseudoalteromonas phages, as determined by plaque assay, at each station (1993; O: $1994 ; \otimes$ : both years)

species infecting Pseudoalteromonas spp. in the North Sea. Our previous work on DNA homologies among 22 different marine phages, as determined by DNA-DNA hybridization, showed that the whole DNA of each phage was specific for only 1 phage species (Wichels et al. 1998). These results suggest that phage DNA can be used as specific DNA probes in order to identify single phage species. Data elucidating the genetic relatedness and host range of Helgoland phages and North Sea phages are presented.

\section{MATERIALS AND METHODS}

Water samples were collected during 3 cruises to the North Sea. Samples were tested for plaque formation on 70 bacterial isolates belonging to the genus Pseudoalteromonas. After isolation and purification of the new Pseudoalteromonas spp. phages, they were characterized by DNA hybridization and host range cross-reaction test, in order to assign them to a virus family and a phage species.

Bacterial strains, phages and media. Seventy marine bacterial host strains and 13 lytic phages were provided by Moebus $(1992 \mathrm{a}, \mathrm{b})$. They were isolated from water samples collected at Helgoland Roads (HR; 54 $09^{\prime} \mathrm{N}$, $7^{\circ} 52^{\prime} \mathrm{E}$; Fig. 1), which is located approximately $55 \mathrm{~km}$ offshore in the German Bight. In order to characterize the 70 host bacteria, colony hybridization was performed under stringent conditions with group-specific 5' labeled digoxygenine DNA probes (EUB 338, GAM 42a, ALT 1413, PSA 184; Table 1; Eilers et al. 2000).

Thirteen PHS from this Moebus collection were chosen randomly to investigate the occurrence of specific PHS in the North Sea. The phages had been characterized previously by electron microscopy, DNA-DNA hybridization and host range (Wichels et al. 1998). They represent 3 virus families within the order Caudovirales (tailed bacteriophages): 6 Myoviridae, 4 Siphoviridae and 3 Podoviridae. Each phage lyses at least 1 of the 70 bacterial strains tested. According to their host range, they were assigned to host sensitivity groups (SGs) as follows: SGI, highly host specific (1 host); SGII, broad host range (2 to 10 host bacteria); and SGIII, broadest host range (11 to 36 host bacteria) (Table 2). These phages are now termed Helgoland phages.

Sampling of seawater. For the isolation of marine phages during 3 North Sea cruises with RV 'Heincke' in September 1993 (Cruise HE49), in April (Cruise HE54) and October 1994 (Cruise HE65), water samples were collected at 19 stations on a transect from the Elbe estuary to west Norwegian coastal waters (Fig. 1). At each of the stations, $100 \mathrm{l}$ of water was pumped from $1 \mathrm{~m}$ depth through a pre-filter cascade $(100,50$ and $10 \mu \mathrm{m}$ gauze filters) followed by $3 \mu \mathrm{m}$ filtration (cellulose nitrate). Water was concentrated by using an ultrafiltration system (Amicon hollowfiber cartridge, molecular cut off $100000 \mathrm{Da}$ ) as described by Suttle et al. (1991). The final volume of the phage-containing samples was ca. $100 \mathrm{ml}$ (i.e. concentration factor 1000). In order to remove bacteria, they were filtered through $0.15 \mu \mathrm{m}$ cellulose nitrate filters. In avoiding phage adsorption, filters were pre-washed with sterile $3 \%$ beef-extract solution. Phage-containing samples were stored at $4^{\circ} \mathrm{C}$ until use. Filtration units were sterilized between samplings. 
Plaque detection and isolation of phages. For the detection of plaques, 70 bacterial host strains were used. Double layer agar plates $(10 \mathrm{ml}$ bottom layer, $3 \mathrm{ml}$ soft agar upper layer) were prepared as described by Wichels et al. (1998). Phage-containing samples obtained from the 3 North Sea cruises were tested for plaque formation. All 70 bacterial host strains were used as targets. The soft agar was mixed with ca. $10^{8}$ bacteria (liquid culture). Immediately after solidification each phagecontaining sample was dotted $(10 \mu \mathrm{l})$ onto the upper layer with a multi-inoculator (Moebus 1980). Plaque formation was determined after incubation overnight at $18^{\circ} \mathrm{C}$ in the dark. If no plaques were formed, $1 \mathrm{ml}$ of each phage-containing sample was plated onto a second set of double layer agar plates. For isolation and purification of single plaques, dilution series were prepared from positive phage-containing samples. Plaques were examined after incubation (for conditions, see above) and isolated. Purified phage stocks (lysates) were prepared according to Moebus (1980). We will further refer to these phages isolated from water samples taken during the cruises as North Sea phages. For phage-host cross-reaction tests, double layer agar plates were prepared. Phage stocks of the North Sea phages were dotted in a dilution series of $10^{0}$ to $10^{-6}$ onto the upper layer. This was essential for differentiation between clear lysis reaction (plaque formation) and inhibition of the bacterial lawn. Depending on the number of lysed bacterial isolates, phages were assigned to host SGs (Wichels et al. 1998).

Isolation of phage DNA. For each of the isolated North Sea phages, stock solution lysates of $20 \mathrm{ml}$ were prepared (Moebus 1980). DNA was isolated according to Sambrook et al. (1989) and by omitting the chloroform step of that method.

Phage DNA probes and DNA-DNA hybridization. Phage DNA probes of the 13 Helgoland phages (Table 2) were made (Wichels et al. 1998). For dot blot hybridization, whole phage DNA of each of the North Sea phages (5 to $10 \mu \mathrm{l}$ ) was dotted onto nylon membranes (Hybond $N$, Amersham) and immobilized by UV light $\left(\lambda_{312 \mathrm{~nm}}, 7 \mathrm{~min}\right)$. DNA-DNA hybridization was carried out under stringent conditions $\left(68^{\circ} \mathrm{C}\right.$ for $\left.16 \mathrm{~h}\right)$. Hybridization was detected according the manufacturer's protocol (Boehringer Mannheim). Positive hybridization signals occurred after 1 to $4 \mathrm{~h}$ of incubation.

\section{RESULTS}

\section{Occurrence of plaque-forming units in North Sea water samples}

Water samples taken during 3 cruises with RV 'Heincke' in 1993 and 1994 (Fig. 1) and were tested for plaque formation with 70 bacterial strains. The characterization of these bacteria, carried out by colony hybridization with group-specific digoxygenine labeled DNA probes, showed that all 70 bacterial host strains belong to the genus Pseudoalteromonas (data not shown).

In water samples taken in September 1993 (cruise HE49), plaque formation was observed at 4 stations (Stns 3, 4, 6 and 10) in the German Bight and in Danish coastal waters (Fig. 1, Table 3). In total, 13 plaque reactions occurred with at least 1 of the 70 bacterial host strains tested. Twelve new phages were isolated; 1 phage was lost during the isolation procedure.

In water samples taken in October 1994 (Cruise HE65), plaque formation was detected at 5 stations (Stns 5 to 9) (Fig. 1, Table 3). In total, 33 plaque reac- 
tions were observed with at least 1 of the 70 bacterial isolates tested. Most plaque reactions were detected at Stn 6 near Helgoland.
During Cruises HE49 and HE65, no plaques were detected in samples collected from Norwegian waters (HE49: Stns 11 to 19 and HE65: Stns 10 to 19). This was

Table 3. Comparison of 45 North Sea phages (Cruises HE49 and HE65) by DNA-DNA hybridization. Phages were isolated from seawater samples of RV 'Heincke' Cruises HE49 and HE65 (September 1993 and October 1994). SG: sensitivity group; SGI: highly host specific (1 host); SGII: broad host range (2 to 10 host bacteria); SGIII: broadest host range (11 to 36 host bacteria); • positive hybridization signal

\begin{tabular}{|c|c|c|c|c|c|c|c|c|c|c|c|c|}
\hline \multirow[t]{3}{*}{ Stn } & \multicolumn{3}{|c|}{ Virus family } & \multicolumn{8}{|c|}{ Helgoland phages } & \multirow[b]{2}{*}{ — Podoviridae — } \\
\hline & \multirow[t]{2}{*}{ Host } & \multirow{2}{*}{$\begin{array}{l}\text { Probe } \\
\text { phage }\end{array}$} & \multirow{2}{*}{$\begin{array}{l}\text { Host } \\
\text { SG }\end{array}$} & \multicolumn{5}{|c|}{ - Myoviridae } & \multicolumn{3}{|c|}{ Siphoviridae } & \\
\hline & & & & $\mathrm{H} 7 / 2$ & H106/1 & $\mathrm{H} 114 / 2$ 6-8a & $6-42 \mathrm{c}$ & $12-13 a$ & $\mathrm{H} 103 / 1$ & $\mathrm{H} 118 / 1$ & $10-77 a \quad 11-68 c$ & $\mathrm{H} 71 / 2 \quad \mathrm{H} 100 / 1 \quad 10-33 \mathrm{~b}$ \\
\hline \multicolumn{13}{|c|}{ HE 49} \\
\hline 3 & $13-15$ & $\mathrm{FI} / 15$ & II & & & & & & & • & & \\
\hline 4 & H100 I & No lysatec $^{\mathrm{a}}$ & II & & & & & & & & & \\
\hline 4 & H114 & $\mathrm{FI} / 3$ & II & & & & & • & & & & \\
\hline 4 & H114 & $\mathrm{FI} / 12$ & II & & & & & & & • & & \\
\hline 4 & H103 & $\mathrm{FI} / 4$ & II & & & & & & • & & & \\
\hline 4 & H103 & $\mathrm{FI} / 5$ & II & & & & & & - & & & \\
\hline 4 & H105 & $\mathrm{FI} / 6$ & II & & & & & & - & & & \\
\hline 4 & H105 & $\mathrm{FI} / 7$ & II & & & - & & & & & & \\
\hline 4 & $10-94$ & $\mathrm{FI} / 8$ & II & & & & & & & - & & \\
\hline 4 & $10-94$ & $\mathrm{FI} / 13^{\mathrm{b}}$ & II & & & - & & & - & & & \\
\hline 4 & $13-15$ & $\mathrm{FI} / 14^{\mathrm{b}}$ & II & & & - & & & - & & & \\
\hline 6 & H114 & $\mathrm{FI} / 2$ & II & & & & & - & & & & \\
\hline 10 & H114 & FI/1 & II & & & & & & & - & & \\
\hline \multicolumn{13}{|c|}{ HE 65} \\
\hline 5 & H106 & FIII/8 & I & & • & & & - & & & & \\
\hline 5 & M109 & FIII/33 & II & & & & - & & & & & \\
\hline 6 & $12-4$ & FIII/28 & III & & & & • & & & & & \\
\hline 6 & $1-23$ & FIII/14 & I & & & & & & & & & \\
\hline 6 & $10-103$ & FIII/26 & I & & & & • & & & & & \\
\hline 6 & $10-52$ & FIII/23 & III & & & & - & & & & & \\
\hline 6 & $10-94$ & FIII/25 & III & & & & • & & & & & \\
\hline 6 & $11-68$ & FIII/27 & III & & & & - & & & & & \\
\hline 6 & $13-15$ & FIII/30 & III & & & & - & & & & & \\
\hline 6 & $5-34$ & FIII/16 & III & & & & & & & & & \\
\hline 6 & $5-68$ & FIII/17 & III & & & & • & & & & & \\
\hline 6 & $6-42$ & FIII/18 & III & & & & • & & & & & \\
\hline 6 & $6-62$ & FIII/19 & III & & & & • & & & & & \\
\hline 6 & $6-92$ & FIII/20 & III & & & & • & & & & & \\
\hline 6 & H118 & FIII/11 & III & & & & • & & & & & \\
\hline 6 & $\mathrm{H} 74$ & FIII/31 & III & & & & & & & & & \\
\hline 6 & M109 & FIII/32 & III & & & & & & & & & \\
\hline 7 & $5-34$ & FIII/15 & III & & & & & & - & & & \\
\hline 7 & H118 & FIII/10 & II & & & & & & & - & & \\
\hline 7 & H137 & FIII/12 & III & & & - & & & & & & \\
\hline 7 & H139 & FIII/13 & II & & & & & & - & & & \\
\hline 7 & H71 & FIII/1 & I & & & & & & & & & \\
\hline 8 & $9-12$ & FIII/22 & I & & & & & & - & & & \\
\hline 9 & $9-12$ & FIII/21 & II & & & & & & - & & & \\
\hline 9 & $10-77$ & $\mathrm{FIII} / 24$ & I & & & & & & & & - & \\
\hline 9 & $12-13$ & FIII/29 & II & & - & & & - & & & & \\
\hline 9 & $\mathrm{H} 100$ & FIII/2 & II & & & & & & & & & \\
\hline 9 & H101 & FIII/3 & II & & & & & & - & - & & \\
\hline 9 & H102 & FIII/4 & II & & & & & & - & - & & \\
\hline 9 & H103 & $\mathrm{FIII} / 5^{\mathrm{b}}$ & II & & & & & & - & & & • \\
\hline 9 & H105 & $\mathrm{FIII} / \mathrm{6}^{\mathrm{b}}$ & II & & & & & & • & & & - \\
\hline 9 & H106 & FIII/7 & II & & • & & & • & & & & \\
\hline 9 & H108 & FIII/9 ${ }^{\mathrm{b}}$ & II & & & & & & - & & & - \\
\hline
\end{tabular}


Table 4. Host-phage cross-reaction tests of 12 phages (Cruise HE49) with 70 Pseudoalteromonas spp. bacterial strains (from Helgoland waters; 1990). Only bacterial strains with positive results are depicted. •: positive cross-reaction; nd: not determined

\begin{tabular}{|c|c|c|c|c|c|c|c|c|c|c|c|c|}
\hline \multicolumn{13}{|c|}{ North Sea phages (HE49) } \\
\hline Stn: & 3 & 4 & 4 & 4 & 4 & 4 & 4 & 4 & 4 & 4 & 6 & 10 \\
\hline Phage: & FI/15 & $\mathrm{FI} / 3$ & $\mathrm{FI} / 4$ & $\mathrm{FI} / 5$ & $\mathrm{FI} / 6$ & $\mathrm{FI} / 7$ & $\mathrm{FI} / 8$ & $\mathrm{FI} / 12$ & FI/13 & FI/14 & $\mathrm{FI} / 2$ & $\mathrm{FI} / 1$ \\
\hline \multicolumn{13}{|c|}{ Genetically related phage species: } \\
\hline & H118/1 & $12-13 a$ & H103/1 & H103/1 & H103/1 & $\mathrm{H} 114 / 2$ & H118/1 & H118/1 & nd & nd & $12-13 a$ & H118/1 \\
\hline \multicolumn{13}{|c|}{ Host bacteria } \\
\hline H103 & & $\bullet$ & $\bullet$ & $\bullet$ & $\bullet$ & $\bullet$ & & $\bullet$ & $\bullet$ & & $\bullet$ & $\bullet$ \\
\hline H105 & & $\bullet$ & - & $\bullet$ & $\bullet$ & $\bullet$ & $\bullet$ & $\bullet$ & $\bullet$ & & $\bullet$ & $\bullet$ \\
\hline H108 & & - & $\bullet$ & $\bullet$ & $\bullet$ & $\bullet$ & - & • & - & & - & - \\
\hline H114 & & $\bullet$ & $\bullet$ & & $\bullet$ & & & $\bullet$ & & • & $\bullet$ & • \\
\hline $10-94$ & $\bullet$ & & & & $\bullet$ & • & • & & • & • & & \\
\hline $13-15$ & $\bullet$ & & & & $\bullet$ & • & $\bullet$ & & $\bullet$ & • & & \\
\hline
\end{tabular}

also true for the samples of the Elbe estuary (HE49: Stns 1 and 2, and HE65: Stns 1 to 4). No plaque reactions were observed in samples taken during Cruise HE54 (April 1994). In total, 45 North Sea phages were isolated (HE49: 12 phages; HE65: 33 phages).

\section{Genetic relationship of newly isolated phages}

Forty-five North Sea phages were compared with the 13 Helgoland phages by DNA-DNA hybridization (Wichels et al. 1998). Hybridization was performed with whole phage DNA (Table 3). Thirty-nine of the North Sea phages showed DNA homology with one of the Helgoland phages, which comprise the 3 virus families (Table 2) tested. Accordingly, 19 North Sea phages were assigned to the family Myoviridae (Cruise HE49: 3; Cruise HE65: 16) and 15 to the family Siphoviridae (Cruise HE49: 7; Cruise HE65: 8). Three North Sea phages (Cruise HE65) showed DNA homologies with Podoviridae. In samples of cruise HE49 no Podoviridae were found. Five phages displayed DNA homologies with the DNA of different families (Phages FI/13, F1/14 and FIII/5, FIII6 and FIII9; Table 3). These results are ambiguous, since even fresh phage lysates from single plaques dis-

Table 5. Comparison of host ranges of the 2 groups of Pseudoalteromonas spp. phages investigated: 13 Helgoland phages (isolation 1990) and 39 North Sea phages (isolation 1993 and 1994). Host ranges of both phage groups were tested on 70 marine bacteria of the genus Pseudoalteromonas

\begin{tabular}{|lcc|}
\hline Host SG & $\begin{array}{c}\text { Helgoland } \\
\text { phages (\%) }\end{array}$ & $\begin{array}{c}\text { North Sea } \\
\text { phages (\%) }\end{array}$ \\
\hline SGI, highly host specific (1 host) & 54 & 16 \\
SGII, broad host range (2 to 10 hosts) & 31 & 51 \\
SGIII, broadest host range (11 to 36 hosts) & 15 & 33 \\
\hline
\end{tabular}

played the same results. At Stn 6 near Helgoland (Cruise HE65), most hybridization signals occurred with the DNA probe of phage species 6-42c (Myoviridae).

By combining both of the techniques - DNA homology studies and host range cross-reaction testphages of a single species were differentiated into phage strains as follows:

(1) Phages of the same species (i.e. showing DNA homologies) also displaying identical host range were considered to be identical strains of 1 species. For example, Phages FI/2 and FI/3 (Table 3) were assigned to species 12-13a, although they were isolated at different stations (Stns 4 and 6, respectively). Since these 2 phages had the same host ranges (Table 4), they were considered to be identical. Another 3 North Sea phages of Cruise HE65 (FIII/25, FIII/26 and FIII/30; Table 3 ) that showed identical host sensitivity patterns (data not shown) were also considered to be identical. Three phages isolated at Stn 9 (FIII/5, FIII/6 and FIII/9) that showed DNA homologies with 2 virus families (Table 3) had identical host sensitivity patterns and thus were considered to be identical.

(2) Phages of one species that exhibited different host ranges were considered to display different phage strains (e.g. 3 phages of phage species H103/1 isolated from Stn 4: FI/4, FI/5 and FI/6; Table 4). Finally, in total 39 of the 45 North Sea phages isolated during Cruises HE49 and HE65 were considered to belong to different phage strains.

Phage-host cross-reaction tests of these 39 different North Sea phages showed that the majority of the phages (33 phages) lyse more than one of the bacterial strains (Table 5). Thirteen phages had a very broad host range and were assigned to SGIII (i.e. those that lyse more than 11 of the 
bacterial strains of all 70 bacteria tested). Twenty phages were assigned to SGII (those that lyse 2 to 10 bacterial strains of all 70 bacteria tested). The $13 \mathrm{Hel}-$ goland phages showed significant differences in host range from the North Sea phages (Table 5). Seven Helgoland phages belonged to SGI, whereas only 6 of the 39 North Sea phages were highly host specific (SGI). Statistical analysis (Mann-Whitney rank sum test, SigmaStat. version 1.0) revealed that the 2 groups are significantly different $(T=237.5, \mathrm{p}<0.0244)$.

\section{DISCUSSION}

The mean concentration of VLPs in the aquatic environment ranges between $10^{7}$ and $10^{11} \mathrm{VLPs} \mathrm{l}^{-1}$ (Bergh et al. 1989, Cochlan et al. 1993, Wommack \& Colwell 2000). However, these marine VLPs are still considered a 'black box'. It is not clear which groups of viruses are present in the natural environment (bacteriophages and viruses of phyto- or zooplankton) and how they are distributed. Furthermore, it is unknown whether these particles are infectious and which bacterial groups can be infected. In comparison to VLP counts, the determination of phage titer (plaque assays) is an additional sensitive tool for the detection of bacteriophages. However, the detection and isolation of specific phages by plaque assays is limited since bacterial hosts have to be available for this. On the other hand, plaque assays are limited, as they do not provide further information on the phages (e.g. morphological or genetic affiliation). Pseudoalteromonas spp. phages representing all 3 virus families show a very diverse morphology with regard to DNA composition and host range. On the basis of a species concept for bacteriophages (Ackermann et al. 1992), Wichels et al. (1998) showed that the whole phage DNA can be used as a species-specific DNA probe. Their studies on the DNA homologies of the marine Pseudoalteromonas spp. phages demonstrated that positive hybridization signals were detected exclusively among phages of the same virus family. In the present study this concept was used to investigate the occurrence of Pseudoalteromonas spp. phages in the North Sea by DNA-DNA hybridization using specific phage DNA probes. However, from 45 isolated phages, $85 \%$ were assigned to marine phage species already described. From their DNA homology, 27 phages were assigned to individual phage species. In contrast to the species concept of Ackermann et al. (1992), 5 phages showed DNA homologies with 2 virus families. This may be due to DNA fragments, which can be transferred to different phage species via double infection with 2 phages and homologue recombination (Botstein 1980, Gibbs 1987). Double infection of a bacterial host by different phages and homologue recombination or incorrect excision and packaging of the phage DNA may lead to the transfer of DNA fragments of different origin. This is discussed as a fundamental idea for a model of modular evolution for viruses (Kim \& Davidson 1974, Mise 1976, Schwarz et al. 1983, Gibbs 1987, Jarvis 1995).

The North Sea phages as detected by plaque assays occurred in water samples of the German Bight between $53^{\circ} 30^{\prime}$ and $57^{\circ} 00^{\prime} \mathrm{N}$ latitude. The Pseudoalteromonas spp. host strains were isolated near Helgoland. Since phages depend on the presence of their specific host bacteria, these results may indicate the distribution limits of the Pseudoalteromonas spp. host strains. One of the limiting factors may be the low salinity in the river Elbe and its estuary, with 15 PSU at low and 20 PSU at high tide. Salinity in the German Bight ranges between 29 and 36 PSU. In regions north of $57^{\circ} 00^{\prime} \mathrm{N}$ latitude it can be assumed that the influence of the Atlantic and the Skagerrak may function as a natural barrier causing the limiting geographical PHS distribution.

At present no information exists concerning the distribution patterns of specific bacteria in the North Sea. Hence, until now there has also been insufficient information concerning the geographical distribution of phage species. The most 'common' phage species found in this study was Siphovirus H103/1. This species was detected in samples of Cruises HE49 and HE65 at 4 different stations (Stns 4, 7, 8 and 9). Remarkably, the different strains of Siphovirus H103/1 displayed various host sensitivity patterns representing all 3 host SGs. Another common phage species, Myovirus 6-42c, was detected at only a single station. Within this species, strains of different SGs were also present. These data underscore the high diversity of Pseudoalteromonas spp. phages on a high phylogenetic level. Moebus (1983), who isolated bacteria from the Bay of Biscay and the Atlantic, observed the restricted distribution of specific PHS indirectly by comparison of phage-host cross-reaction tests. Kellogg et al. (1995) investigated the distribution of genetically related vibriophages, which lyse Vibrio parahaemolyticus. These phages were found over great geographical distances of ca. 4500 miles $(\sim 7241 \mathrm{~km})$ in the Atlantic and Pacific Oceans. However, our data provide clues for the varying distribution of different Pseudoalteromonas spp. phage species in space and time. Some of the specific phage species were detected in a narrow region between $53^{\circ} 30^{\prime}$ and $57^{\circ} 00^{\prime} \mathrm{N}$ latitude. Other phage species were found at only a single station. Some phage species occurred over an extended period of time (1993 and 1994); others were detected only once. Wommack et al. (1999) investigated the community structure of virioplankton in Chesapeake Bay. These authors also found temporal 
changes of virus populations by using the pulsed field gel electrophoresis (PFGE) fingerprint technique. PFGE analysis of natural complex virioplankton allows the separation of individual virus strains according to their genome size.

Statistical analysis of host ranges revealed that the Helgoland phages, which are highly host specific, were significantly different from the North Sea phages, with broader host ranges. These differences may be a consequence of an isolation strategy. The Helgoland phages were isolated using enrichment cultures (Moebus 1980), while the North Sea phages were isolated after enrichment of VLPs by ultrafiltration. On the other hand, the North Sea phages, which exhibit a broader host range, might be 'host range mutants' of the original phage species. The North Sea phages were isolated in 1993 and 1994, and the genetically related Helgoland phages were isolated in 1990 in the same general geographical area. Lenski (1987) showed that phage mutants may acquire the potential of an extended host range. The extended host range can improve the ability of propagation and thus may be interpreted as a survival strategy.

The North Sea phages isolated during Cruises HE49 and HE65 are genetically related to the Helgoland phages. Since these Pseudoalteromonas spp. phages were found frequently within several years in a narrow geographical region of the North $\mathrm{Sea}$, it can be assumed that this group constitutes a significant and stable phage population in this area, but changes in phage sensitivity and host range frequently occur. Hence, further investigation is needed to elucidate by which quantitative and qualitative means Pseudoalteromonas spp. phages control their host bacteria.

Acknowledgements. We are very grateful to the crew of the RV 'Heincke'. We thank Jakob Pernthaler for critically reviewing the manuscript. This investigation was supported by a grant from the Biologische Anstalt Helgoland, Germany.

\section{LITERATURE CITED}

Ackermann HW, DuBow MS, Jarvis AW, Jones LA and 10 others (1992) The species concept and its application to tailed phages. Arch Virol 124:9-82

Amann R, Binder BJ, Olson RJ, Chisholm SW, Devereux R, Stahl DA (1990) Combination of 16S rRNA-targeted oligonucleotide probes with flow-cytometry for analyzing mixed microbial populations. Appl Environ Microbiol 56: 1919-1925

Bergh O, Børsheim KY, Bratbak G, Heldal M (1989) High abundances of viruses found in aquatic environments. Nature 340:467-468

Botstein D (1980) A theory of modular evolution for bacteriophages. Ann NY Acad Sci 354:484-491

Bratbak G, Thingstad F, Heldal M (1994) Viruses and the microbial loop. Microb Ecol 28:209-221
Cochlan WP, Wikner J, Steward GF, Smith DC, Azam F (1993) Spatial distribution of viruses, bacteria and chl a in neritic, oceanic and estuarine environments. Mar Ecol Prog Ser 92:77-87

Eilers H, Pernthaler J, Glöckner FO, Amann R (2000) Culturability and in situ abundance of pelagic bacteria from the North Sea. Appl Environ Microbiol 66:3044-3051

Fuhrmann JA, Suttle CA (1993) Viruses in marine planktonic systems. Oceanography 6:51-63

Gibbs A (1987) Molecular evolution of viruses: 'trees', 'clocks' and 'modules'. J Cell Sci (Suppl) 7:319-337

Jarvis AW (1995) Relationship by DNA homology between lactococcal phages 7-9 and New Zealand industrial lactococcal phages. Int Dairy J 5:355-366

Kellogg CA, Rose JB, Jiang SC, Thurmond JM, Paul JH (1995) Genetic diversity of related vibriophages isolated from marine environment around Florida and Hawaii, USA. Mar Ecol Prog Ser 120:89-98

Kim JS, Davidson N (1974) Electron microscope heteroduplex study of sequence relations of T2, T4, and T6 bacteriophage DNAs. Virology 57:93-111

Lenski RE (1987) Dynamics of interactions between bacteria and virulent bacteriophage. Adv Microbiol Ecol 1:1-44

Manz W, Amann R, Ludwig W, Wagner M, Schleifer KH (1992) Phylogenetic oligodeoxynucleotide probes for the major subclasses of Proteobacteria: problems and solutions. Syst Appl Microbiol 15:593-600

Mise K (1976) Recombinants between P22 and P1Cm. Virology 71:531-545

Moebus K (1980) A method for the detection of bacteriophages from ocean water. Helgol Wiss Meeresunters 34: $1-14$

Moebus K (1983) Lytic and inhibition response of bacteriophages among marine bacteria, with special reference to the origin of phage-host systems. Helgol Wiss Meeresunters 36:375-391

Moebus K (1992a) Preliminary observations on the concentration of marine bacteriophages in the water around Helgoland. Helgol Wiss Meeresunters 45:411-422

Moebus K (1992b) Further investigations on the concentration of marine bacteriophages in water around Helgoland, with references to the phage host systems encountered. Helgol Wiss Meeresunters 46:275-292

Moebus K, Nattkemper H (1981) Bacteriophage sensitivity patterns among bacteria isolated from marine waters. Helgol Wiss Meeresunters 34:375-385

Sambrook J, Fritsch EF, Maniatis T (1989) In: Ford N (ed) Molecular cloning: a laboratory manual, Vol 1-3. Cold Spring Harbor Laboratory Press, Cold Spring Harbor, NY

Schwarz H, Riede I, Sonntag I, Henning U (1983) Degrees of relatedness of T-even type E. coli phages using different or the same receptors and topology of serologically crossreacting sites. EMBO J 2:375-380

Suttle CA, Chan AM, Cottrell MT (1991) Use of ultrafiltration to isolate viruses from seawater which are pathogens of marine phytoplankton. Appl Environ Microbiol 57: 721-726

Wichels A, Biel SS, Gelderblom HR, Brinkhoff T, Muyzer G, Schütt C (1998) Bacteriophage diversity in the North Sea. Appl Environ Microbiol 64:4128-4133

Wommack KE, Colwell RR (2000) Virioplankton: viruses in aquatic ecosystems. Microbiol Mol Biol Rev 64:69-114

Wommack KE, Ravel J, Hill RT, Chun J, Colwell RR (1999) Population dynamics of Chesapeake Bay virioplankton: total-community analysis by pulsed-field gel electrophoresis. Appl Environ Microbiol 65:231-240 